\title{
Managing plant-environment-symbiont interactions to promote plant performance under low temperature stress
}

\author{
Omid Askari-Khorasgani ${ }^{1}$, Harlene Hatterman-Valenti ${ }^{2}$, Francisco Borja Flores \\ Pardo $^{3}$, Mohammad Pessarakli ${ }^{*}$ \\ ${ }^{1}$ Young Researchers and Elite Club, Department of Horticulture, College of Agriculture and \\ Natural Resources, Isfahan (Khorasgan) Branch, Islamic Azad University, Isfahan, Iran \\ ORCID: https://orcid.org/0000-0002-8956-5977 \\ ${ }^{2}$ Professor, Department of Plant Sciences, North Dakota State University, P.O. Box \\ 6050, Dept. 7670, Fargo, ND 58108-6050 \\ ${ }^{3}$ Tenured Scientist in Plant Biology, Department of stress biology and plant pathology, \\ CEBAS-CSIC, P.O. Box 164, 30100, Espinardo-Murcia, Spain ORCID: \\ https://orcid.org/0000-0002-9883-9458 \\ ${ }^{4}$ Professor, School of Plant Sciences, College of Agriculture and Life Sciences, The \\ University of Arizona, Tucson, AZ 85721, USA ORCID: https://orcid.org/0000-0002-7662- \\ 2258 * Corresponding Author E-mail: Mohammad Pessarakli pessarak@email.arizona.edu
}

\begin{abstract}
Low temperature stresses, also referred to as cold temperature stresses, including chilling and freezing temperatures, are among the major abiotic stresses that severely reduces plant yield, quality, and marketability and pose a serious threat to plant production during whole plant life cycles. Plant-environment-symbiont interactions determine the symbiotic and crop performance and tolerance to biotic and abiotic stresses. To achieve the optimum outcome, it is essential to consider not only plantsymbiont relationships, but also symbiont adaptation and symbiont-symbiont interactions. Improving multi-symbiotic component systems and symbiont breeding together can be a useful strategy to improve symbiosis and, thus, crop production. In this review article, role of interactions between multi-symbiotic components and plantenvironment-symbiont relationships and the related biotechnology approaches are discussed in order to find the most effective sustainable and environmentally friendly agricultural practices to improve crop performance and mitigate the adverse effects of low temperatures on plants.
\end{abstract}


Key words: arbuscular mycorrhizal fungi, rhizobacteria, chilling, freezing, microbiome, multisymbiotic relationships, symbiosis, cold stress

\section{CONTACT: Mohammad Pessarakli, Professor pessarak@email.arizona.edu School of Plant Sciences, College of Agriculture \& Life Sciences, The University of Arizona, Tucson, Arizona 85721, USA.}

\section{Introduction}

Low temperature stresses, including chilling and freezing temperatures, are among the major abiotic stresses that severely disturb agricultural system and ecosystem biodiversity worldwide, and lower plant quality, yield and, thus, economic value of the produce (Chen et al. 2014). Plant responses to low temperatures greatly vary in the plant kingdom. On sensing freezing or chilling, plants use adaptation mechanisms known as cold acclimation that activates signalling pathways, triggering genes at the transcriptional and post-transcriptional levels to modify plant biochemistry and metabolism, inducing changes in proteins, proline, soluble sugars, osmolytes, and membrane lipid composition and peroxidation. Cold acclimation processes induce antioxidant activity, stabilization of cellular components, enzymes, and other macromolecules to maintain their biological activities, prevention or diminution of freezing or chilling injury and dehydration, extending the freezing tolerance and survival under cold stress conditions (Kishitani et al. 1994; Warren 1998; Thomashow 1999; Kwon et al. 2007; Liu and Osborne 2008; Abdel Latef and Chaoxing 2011; Ouellet and Charron 2013; Strimbeck et al. 2015).

Co-evolution of plant-microbiome metaorganisms is determinant for plant growth, health, fitness, quality, productivity, diversity, and tolerance to biotic and abiotic stresses (Berg et al. 2016). Rhizospheric and phyllospheric (epiphytic), and endospheric (endophytic) microbiome consisted of bacteria, archaea, fungi (mycoflora), and protists are collectively referred to as plant growth promoting microbiota (Afifi 1984; Berg et al. 2016). Plant symbiotic relationship with symbionts such as arbuscular mycorrhizal fungi (AMF) benefits crop productivity and tolerance to different biotic and abiotic stress conditions, ecosystem biodiversity, soil health (i.e., structure, chemical composition, aggregation, degradation, organic matter decomposition, water and nutrient availability, reclamation, as well as enzymatic and microorganisms activity), and mitigates the adverse effects of climate change by, for example, improving nitrogen uptake by $\mathrm{N}_{2}$-fixation, reducing input of synthetic 
fertilizers and, thus, reducing $\mathrm{N}_{2} \mathrm{O}$ emission (Medina and Azcón 2010; Abdel-Fattah and Asrar 2012; Berruti et al. 2015). Accordingly, this review article evaluates multi-symbiotic component interactions, and relationships between plants, environment conditions, and symbionts to provide the information for appropriate agricultural managements required for improving crop and symbiotic performance and, thus, tolerance to low temperature conditions.

\section{Plant-fungal and plant-bacteria symbiosis and their roles in plant performance} and stress tolerance

Mycorrhizae are fungi that colonize the host plant's root tissues, either intracellularly as arbuscular mycorrhizal fungi (AMF) or extracellularly as ectomycorrhizal fungi. Though the association mainly benefits both plant and fungal symbionts, in some specific species or circumstances the mycorrhizae may be considered parasitic (Johnson et al. 1997). AMF symbiosis is found in more than $80 \%$ of vascular plant species (Schüßler et al. 2001; Abdel Latef and Chaoxing 2011; Fan and Liu 2011). AMF species-specific differences even within the same genus may confer differential symbiotic responses (Varga and Kytöviita 2016). AMF belong to a monophyletic phylum, the Glomeromycota. AMF are obligate symbionts since they need to assimilate carbon from their host plants to complete their life cycle (Abdel Latef and Chaoxing 2011). In return, the fungus provides multiple benefits to the host plant such as improving water and nutrient uptake, water use efficiency (WUE), ion homeostasis and apoplastic and cell-to-cell water transport, photosynthetic pigments content, photosynthetic efficiency, stomatal conductance, gas exchange, osmoregulation, enzymatic and non-enzymatic antioxidant activities, lipid peroxidation, cell membrane stability and permeability, growth, metabolism associated with production of secondary metabolites and tolerance to biotic and abiotic stresses (Evelin et al. 2009; Zhu et al. 2010a; Abdel Latef and Chaoxing 2011; Beltrano and Ronco 2008; Abdel-Fattah and Asrar 2012; Birhane et al. 2012; Chen et al. 2013; Estrada et al. 2013; Quiroga et al. 2017). Agricultural management based on the plant-environment-symbiont relationships would allow farmers to harvest crops with higher quality and improved performance. Just as an example, applying regulated deficit irrigation (RDI) in vineyards improves both fruit quality and AMF colonization (Schreiner et al. 2007). This last process can improve plant cold tolerance directly by adjusting the plant water status and the concentrations of osmolytes and anti-freezing components and indirectly by improving plant-fungi symbiosis. Thus, agricultural management and symbiosis are both critical factors to improve crop performance and tolerance. 
With similar functions, plant-bacteria symbiotic relationship can promote crop performance and tolerance to multiple biotic and abiotic stresses (Fernandez et al. 2012; González and Gonzalez-López 2013). Bacterial symbiosis improves plant tolerance to multiple biotic and abiotic stresses by modulating metabolism (e.g., 1-aminocyclopropane-1carboxylate deaminase (ACCD) activity, tricalcium phosphate solubilization, proline, and osmoregulators, carbohydrates), genetic architecture (e.g., regulation of cold-responsive genes) and photosynthetic capacity and yield of plants (Theocharis et al. 2011; Shahzad et al. 2017; Tiwari et al. 2017). For instance, Burkholderia phytofirmans PsJN colonization imparted long-term chilling stress tolerance to grapevine by modulating host plant carbohydrate metabolism, photosynthesis, and growth under stress conditions (Fernandez et al. 2012).

Numerous studies have demonstrated the effectiveness of AMF on alleviating drought and salinity stresses (Evelin et al. 2009; Fan and Liu 2011; Abdel-Fattah and Asrar 2012; Zhang, Zhang, and Huang 2014; Bernardo et al. 2017; Quiroga et al. 2017; Selvakumar et al. 2017). However, not so much information is available regarding the influence of AMF on conferring tolerance to low temperatures (Charest et al. 1993; Zhu et al. 2010a,b; Zhu et al. 2016; Abdel Latef and Chaoxing 2011; Chen et al. 2013, 2014; Liu et al. 2014) and bacteria (Theocharis et al. 2011; Fernandez et al. 2012; Su et al. 2015; Subramanian et al. 2015, 2016; Srinivasan et al. 2017). More importantly, because of the adverse effects of low temperatures on symbiosis, improving plant and microbiome performance and tolerance to cold stress, which depends on plant-symbiont, symbiont-symbiont interactions, and symbiont activity threshold under cold climatic conditions, requires more investigations.

\section{Symbiosis under low temperatures}

\section{Plant-arbuscular mycorrhizal fungi symbiosis under low temperatures}

Low temperature constraints the penetration and spread of AMF (Gpey 1991). Some studies have shown that mycorrhizal fungi spore germination and hyphae colonization are almost completely inhibited at $10{ }^{\circ} \mathrm{C}$ (Gpey 1991; Wang et al. 2002; Sharma et al. 2013), although the growth of some fungal species may be severely inhibited, but not completely ceased at such low temperatures, for example at $10{ }^{\circ} \mathrm{C}$ for Glomusintraradices and at $5{ }^{\circ} \mathrm{C}$ for Glomus caledonium (Table 1) (Wang et al. 2002; Sharma et al. 2013). AMF capable of growing in cold soils may show contradictory results from beneficial to parasitic relationships 
(Charest et al. 1993; Sharma et al. 2013). This could be due to inability of AMF to uptake and transfer nutrients to the host plant, while consuming plant carbon reservoir (Sharma et al. 2013). The optimum ambient temperature for developing many AMF would be between 20 to $30{ }^{\circ} \mathrm{C}$ with upper and lower activity thresholds of 34 and $16{ }^{\circ} \mathrm{C}$, respectively, for most strains (Wang et al. 2002). Unlike endomycorrhizal arbuscular mycorrhizae (AM), ectomycorrhizae mycelium may remain active at $0{ }^{\circ} \mathrm{C}$ (Sharma et al. 2013). Interestingly, Zhou et al. (2012) study showed that the combined treatment of AMF (Glomus versiforme) along with $50 \mathrm{mg} \mathrm{L}^{-}$ ${ }^{1}$ foliar spray with the synthetic plant growth retardant paclobutrazol (PBZ) effectively reduced chilling injury of Teak (Tectona grandis) seedlings subjected to 6,3 , and $0{ }^{\circ} \mathrm{C}$ for 12 hours. The treatment improved chlorophyll (CHL) content, soluble proteins content, and antioxidant enzymes activities (Table 1) (Zhou et al. 2012). As another strategy to improve symbiotic relationship, the cold-stored mixed inoculum of spores and hyphae of Glomus intraradices and colonized roots of sorghum improved symbiont colonization, soil acid phosphatase activity, phosphorus and nitrogen uptake, CHL content and growth of hot pepper (Table 1) (Kim et al. 2002). Under cold dry climatic conditions, AMF colonization was greatly affected by temperature and rainfall and accordingly varied during the growth seasons (Allen 1983). AM extraradical hyphae have the potential to survive under freezing temperatures (Allen 1983; Kytöviita, 2005; Sharma et al. 2013). Due to the similarities between cold and drought adaptation mechanisms, extraradical AM mycelia are well adapted to tolerate prolonged periods of both cold and drought stresses in habitats with frequent prolonged dry spells such as sand dunes and deserts. AM and ectomycorrhizae mycelia tolerate short-term freezing at least up to $-10{ }^{\circ} \mathrm{C}$ and prolonged freezing at -1 to $-2{ }^{\circ} \mathrm{C}$. Fungal spores have unique adaptation mechanisms that enable them to complete fungal life cycle, withstanding harsh conditions, particularly extreme temperatures. For instance, AM spores remain viable after exposure to $-80{ }^{\circ} \mathrm{C}$ (Sharma et al. 2013). However, under freezing temperatures, it is hypothesized that the effectiveness and nature of symbiotic relationship may be strongly altered and even shifted from endomyrrhizal (i.e., AMF) to ectomycorrhizal fungi relationship (Sharma et al. 2013). Thus, the microbiome selection is critical to enhance symbiotic performance, multi-symbiotic interactions and consequently plant performance and tolerance to multiple stresses. 


\section{Plant-bacteria and plant-yeast symbiosis under low temperatures}

Depending on tolerance threshold to low temperatures, plant growth promoting bacteria (PGPB) and yeast can be distinguished in three groups: (i) extremophilic cold tolerant psychrotrophic (also, known as psychrotolerant) with activity threshold of $4-35{ }^{\circ} \mathrm{C}$; (ii) cold loving psychrophilic bacteria (mostly, consisted of Pseudomonas genus) with activity threshold lower than $15^{\circ} \mathrm{C}$, which can grow at a minimum temperature of $0{ }^{\circ} \mathrm{C}$, with rapid growth between $0.5-7{ }^{\circ} \mathrm{C}$ and no growth at $20{ }^{\circ} \mathrm{C}$, and (iii) psychro-active bacteria that grow at or below $-1{ }^{\circ} \mathrm{C}$ (Witter 1961; Morita 1975; Rayirath et al. 2009; Mishra et al. 2011; Junge et al. 2011; Subramanian et al. 2016).

Similar to AMF, the optimum ambient temperature for many rhizobia are $25-30{ }^{\circ} \mathrm{C}$, with many of these bacteria unable to grow below 10 or at and above $37{ }^{\circ} \mathrm{C}$. However, like arctic rhizobia that grow well at $10{ }^{\circ} \mathrm{C}$, adapted strains are tolerant to heat or freezing temperatures (Graham 1992; Drouin et al. 2000; Alexandre and Oliveira 2013). Colonization of grapevine with plant growth promoting rhizobacterium (PGPR) Burkholderia phytofirmans PsJN (BpPsJN) strongly reduced the chilling-induced damage caused by 5 days of exposure to $4{ }^{\circ} \mathrm{C}$, which could be attained by increasing ROS scavenging, carbohydrate metabolism, and photosynthetic capacity in parallel with the accumulation of more cryoprotective soluble sugars and starch (Table 2) (Theocharis et al. 2011; Fernandez et al. 2012). In Arabidopsis thaliana, BpPsJN root endophytic symbiosis prevented freezinginduced plasmalemma disruption after subjecting the plants to 3 days at $-1{ }^{\circ} \mathrm{C}$ (Table 2) (Su et al. 2015).

In addition to improving photosynthetic capacity and, thus, yield and biomass production, these symbiosis influence carbohydrate metabolism (e.g., trehalose biosynthesis in Pseudomonasfragi P121 (Table 2), Leucosporidium fellii (Table 1), and Mrakia frigida (Table 3), trehalose and glycerol biosynthesis in Saccharomyces cerevisiae, and upregulation of malate dehydrogenase in Rhizobium), which play a crucial role in cold acclimation (Sardesai and Babu 2001; Panadero et al. 2006; Maggi et al. 2013; Mei et al. 2016). The production of unsaturated membrane lipids to maintain membrane fluidity, RNA chaperons to suppress the formation of undesired secondary RNA structures, the synthesis of antifreeze and cold shock proteins, as well as cold-active antioxidant enzymatic and non-enzymatic activities may also have a prominent role in microbiome cold acclimation (Maggi et al. 2013; Ghobakhlou et al. 2013). Since extensive studies indicate that indigenous strains have been resistant and effective in their environmental conditions (Berruti et al. 2015), the breeding 
and selection strategies of these native strains might lead to more successful results. Improving microbiome responses to environmental stimuli can promote symbiotic relationship and, thus, crop performance. Among breeding strategies, regulation of protein homeostasis (e.g., by RNA-binding proteins, transcriptional and post-transcriptional regulation of small non-coding RNAs, RNA chaperons, heat and cold shock protein coding genes, proteases, and proteins involved in exopolysaccharide synthesis), regulation of carbohydrate metabolism (e.g., trehalose and glycerol as mentioned above), enzymes involved in energy generation and redox homeostasis (Fernandez et al. 2012; Maggi et al. 2013; Ghobakhlou et al. 2013; Poltronieri et al. 2014; Keto-Timonen et al. 2016; Zhang et al. 2016; Larrainzar and Wienkoop 2017; Paço et al. 2016; da-Silva et al. 2017; Janczarek et al. 2017; Michaux et al. 2017; Robledo et al. 2017; Yu et al. 2017), genes and enzymes involved in maintaining membrane fluidity, fatty acid composition, plastoquinone state (Maksimov et al. 2017), and nucleic acid metabolism (e.g., by ribonucleotides) (Larrainzar and Wienkoop 2017) are effective tools to confer bacteria resistance to extreme temperatures.

Although the functional mechanisms of these compounds may vary depending on plant species and bacteria strains, the symbiosomes surrounded by a specialized plant membrane peribacteroid membrane have a prominent role in symbiotic performance and tolerance to stresses (Larrainzar and Wienkoop 2017). In addition to conferring microbiome resistant to cold temperatures, regulation of gene expression, e.g. chaperons, proteases, enzymes involved in exopolysaccharides biosynthesis, and small non-coding RNAs can be used to promote symbiotic effectiveness, nodulation, and nitrogen fixation (Paço et al. 2016; da-Silva et al. 2017; Poltronieri et al. 2014; Robledo et al. 2017; Janczarek et al. 2017). In addition to microbiome breeding, because of the close symbionts interactions, such as fungalbacterial genetic and metabolite (e.g., bacterial exopolysaccharides like lipopolysaccharide and chitinase secretion) interactions (Baltrus et al. 2017), the symbionts interactions should be taken into account to draw a sound conclusion about the influence of multi-symbionts on host plants.

\section{Plant-microbe-fungi symbiotic relationships and diversity under low}

\section{temperature}

Bacteria usually establish their symbiotic relationship with fungal hyphae and/or spores, fruiting bodies, and even on mycorrhizal roots. These microbes work in soil primarily in three different ways, i.e. saprotrophy, pathogenicity, and symbiosis. Bacteria in soil move 
towards or along fungal hyphae either by motility or chemotaxis (Hayat et al. 2017). In addition to the interrelationship between bacterial and fungal communities with respect to their structure, diversity, and activity (Tardy et al. 2014; Zhang et al. 2017), they are involved in regulating soil biochemistry (Zhang et al. 2017) and structure (Sessitsch et al. 2001; Gupta 2011; Sun et al. 2015), as well as in plant stress tolerance, content and composition of plant secondary metabolites, nutrient status, productivity and biodiversity (Van der Heijden et al. 1998, 2008, 2016; Hart and Klironomos 2003; Urcelay and Díaz 2003; Hu et al. 2017; Pistelli et al. 2017). Multi-component plant-fungal-bacterial symbiosis has shown higher potential for improving the above mentioned traits, particularly, under stress conditions. Besides, the microorganisms adaptation to stress conditions may be enhanced under the interaction of multiple symbiosis (Shtark et al. 2012, 2015; Van Der Heijden et al. 2016; Rahimzadeh and Pirzad 2017). Soil and also plant fungal and bacterial diversity either in leaves or roots positively mediate plant biodiversity, productivity, and phenotypic traits (Eisenhauer et al. 2017; Laforest-Lapointe et al. 2017).

Mediated by root exudates, plant diversity significantly affects fungal and bacterial biomass and fungal to bacterial biomass ratio. Root exudates influence soil biota diversity, biomass, and function (Eisenhauer et al. 2017) and, in return, synergistically soil biota promotes soil physico-chemical and structural properties and stability (Wright et al. 1999; Sessitsch et al. 2001; Gupta 2011; Sun et al. 2015; Zhang et al. 2017) as well as plant health, growth, productivity, and stress tolerance (Eisenhauer et al. 2017). Soil biochemistry and structure, microbial diversity, ecosystem biodiversity, and environmental alterations such as climate change affect microbial (Sessitsch et al. 2001; Zhang et al. 2017; Hayat et al. 2017; Eisenhauer et al. 2017) and fungal biomass, diversity, and activity (Sun et al. 2015; Zhang et al. 2017; Hu et al. 2017; Eisenhauer et al. 2017). Regarding environmental conditions, soil moisture and texture, clay content, $\mathrm{pH}, \mathrm{CO}_{2}$, nutrient concentration, particularly $\mathrm{C}, \mathrm{N}$ and $\mathrm{P}$, soil respiration, organic matter content and its decomposition, and soil temperature are the main influential factors in determining soil microorganisms' activity, strongly influencing mycorrhizal colonization, hyphae growth, bacterial to fungal ratio, and microbial composition and diversity (i.e., gram positive and negative), biomass and activity (Miltner et al. 2004; Lipson et al. 2005; Lekberg and Koide 2008; Gougoulias et al. 2014; Rinu and Pandey 2010; Classen et al. 2015; Berruti et al. 2015). Although the activity threshold levels of biota strains greatly depend on the species of biota and its host, for many strains soil acidity below $\mathrm{pH} 5.0$, alkalinity above $\mathrm{pH} 8.5$, clay content below $15 \%$, extreme temperatures, extreme moisture 
contents, and high nitrate content severely disturb biota population (Howieson and Ballard 2004).

The bioassociative effect of rhizospheric cold-tolerant Pseudomonas spp. strain NARs1 with effective root nodulating symbiotic $\mathrm{N}_{2}$ fixer Rhizobium leguminosarum-PR1 effectively promoted iron acquisition, nutrient ( $\mathrm{N}$ and $\mathrm{P}$ ) uptake, CHL content, and growth of co-inoculated lentil (Lens culinaris L.) (Tables 1, 2, and 4) (Mishra 2011).The synergistic, antagonistic, parasitic, mutualistic, neutral, amensalistic, commensalistic, and competitive relationships of double or triple AMF-Rhizobium-PGPR on specific plants under different environmental conditions may vary depending on symbiont combinations, abundance, diversity, functional mechanism, host species, and environmental conditions (Zaidi and Khan 2005; Mishra 2011; Berruti et al. 2015; Duperron 2017). In addition to the activities and the tolerance levels to environmental stimuli, it has been hypothesized that different microorganisms such as diverse AMF strains differentially improve antioxidant activities and cold tolerance (Chen et al. 2014). Thus, symbiont diversity and combinations are essential to improve stress tolerance because they are able to modulate different adaptation mechanisms through functional heterogeneity as well as threshold activities, thereby when one strain stops working, the other one may have higher capacity of symbiosis.

Moreover, the synergistic effects between diverse symbionts may increase the potential of conferring stress tolerance and improving crop performance. However, because of differences in reported results of multi-component symbiotic systems, probably due to plant-symbiont and symbiont-symbiont relations, symbionts combinations, diversity and abundance, as well as environmental conditions, the efficiency of mixtures needs to be tested (Zaidi and Khan 2005; Mishra 2011; Berruti et al. 2015). Bradyrhizobium sp. (vigna) and phosphate solubilizing microorganisms (PSM) Pseudomonas striata or Penicillium variable enhanced nodulation, $\mathrm{N}$ and $\mathrm{P}$ uptake and, thus, yield in green gram [Vigna radiata (L.) Wilczek] plants in a sandy clay loam soil, while their symbiotic relationship was negatively affected by the addition of Glomus fasciculatum AM fungus (Table 4) (Zaidi and Khan 2005). Similarly, in green gram (Vigna radiate L.), boron (soil or foliar applied borax solution) had a positive impact on nutrient uptake such as $\mathrm{P}$ and $\mathrm{K}$ and, thus, yield in a borondeficient calcareous soil; however, $\mathrm{N}$ uptake was negatively affected (Padbhushan and Kumar 2015). Among different $\mathrm{N}$ sources, including glycine, ammonium, and nitrate, glycine-treated rice crops maintained high levels of $\mathrm{N}$ uptake, soluble proteins, soluble sugars, proline, antioxidant activities, CHL content, photochemical efficiency, biomass production, energy use efficiency, and root/shoot ratio, strengthening cold acclimation (Xiaochuang et al. 2017). 
Using another microorganisms combination, Azospirillum spp. and Pseudomonas striata, and Rhizobium spp. co-inoculation successfully increased the nodules number, plant dry weight and height, and yield in pigeon pea (Table 4) (Mishra 2011).

In addition to improving cold acclimation and biomass production in bacterized wheat plants, Pseudomonas sp. has also been effective in improving total CHL, anthocyanin, proline, total phenolics, and starch content and reducing the $\mathrm{Na}^{+} / \mathrm{K}^{+}$ratio, and electrolyte leakage, yield and tolerance to multiple stresses (Tables 2 and 4) (Mishra et al. 2012). While increasing anthocyanin, proline, and phenolic contents and reducing electrolyte leakage promote ROS detoxification and, thus, cold acclimation, increasing CHL content and carbohydrate metabolism would be efficient to enhance photosynthesis and crop yield. The possibility of antipathetic symbiosis might be due to microorganisms' competition as a result of nutrients scarcity or unavailability (mainly, C, N, P), the symbiont type and combination, the soil environment, and plant genotype (e.g., hormonal status, physiology and defense characteristics) (Mishra 2011). Thus, understanding symbiont-symbiont and plant-symbiont interactions is necessary in order to improve symbiotic performance under cold temperature stresses.

\section{Conclusions}

In sum, this review remarks that understanding the relationships between symbiotic components (combinations, diversity, tolerance, ratios, abundance, genetic, metabolic and symbiont interactions, threshold activities, adaptation and functional mechanisms), soil characteristics and environmental changes (soil biochemistry and structure, $\mathrm{CO}_{2}$, moisture, nutrient and clay content, $\mathrm{pH}$, temperature, and ecosystem biodiversity) are required to make accurate agricultural management decisions. In addition to managing plant, environment, and multi-symbiotic relationships, symbiotic performance and cold acclimation can be improved by using cold tolerant symbionts and regulating plant and symbiont metabolic pathways.

\section{References}

Abdel-Fattah, G. M., and A.-W. A. Asrar. 2012. Arbuscular mycorrhizal fungal application to improve growth and tolerance of wheat (Triticum aestivum L.) plants grown in saline soil. Acta Physiologiae Plantarum 34(1):267-277. doi: 10.1007/s11738-011-0825-6 
Abdel Latef, A. A. H., and H. Chaoxing. 2011. Arbuscular mycorrhizal influence on growth, photosynthetic pigments, osmotic adjustment and oxidative stress in tomato plants subjected to low temperature stress. Acta Physiologiae Plantarum 33(4):1217-1225. doi: 10.1007/s11738-010-0650-3

Afifi, A. F. 1984. Effect of Plant Volatiles on Rhizospheric and Phyllospheric Mycoflora, In: Being alive on land: Proceedings of the International Symposium on Adaptations to the Terrestrial Environment Held in Halkidiki, eds. N. S. Margaris, M. ArianoustouFaraggitaki, W. C. Oechel, 257-269. Greece. 1982. Springer Netherlands, Dordrecht. doi: 10.1007/978-94-009-6578-2_27

Alexandre, A., and S. Oliveira. 2013. Response to temperature stress in rhizobia. Critical Reviews in Microbiology 39(3):219-228. doi: 10.3109/1040841X.2012.702097

Alizadeh Frutan, M., H. Pirdashti, Y. Yaghoubian, and V. Babaeizad. 2016. Effect of paclobutrazol and priformospora indica inoculation on antioxidant enzymes activity and morphological characteristics of green beans (Phaseoluse vulgaris L.) in chilling stress. Journal of Plant Process and Function 5(15):133-146.

Allen, M. F. 1983. Formation of vesicular-arbuscular mycorrhizae in Atriplex gardneri (Chenopodiaceae): seasonal response in a cold desert. Mycologia 75(5):773-776. doi: $10.2307 / 3792769$

Baltrus, D. A., K. Dougherty, K. R. Arendt, M. Huntemann, A. Clum, M. Pillay, K. Palaniappan, N. Varghese, N. Mikhailova, D. Stamatis, T. B. K. Reddy, C. Y. Ngan, C. Daum, N. Shapiro, V. Markowitz, N. Ivanova, N. Kyrpides, T. Woyke, and A. E. Arnold. 2017. Absence of genome reduction in diverse, facultative endohyphal bacteria. Microbial Genomics 3(2):1-12. doi: 10.1099/mgen.0.000101

Beltrano, J., and M. G. Ronco. 2008. Improved tolerance of wheat plants (Triticum aestivum L.) to drought stress and rewatering by the arbuscular mycorrhizal fungus Glomus claroideum: effect on growth and cell membrane stability. Brazilian Journal of Plant Physiology 20(1):29-37. doi: 10.1590/s1677-04202008000100004

Berg, G., D. Rybakova, M. Grube, and M. Köberl. 2016. The plant microbiome explored: implications for experimental botany. Journal of Experimental Botany 67(4):995-1002. doi: $10.1093 / \mathrm{jxb} / \mathrm{erv} 466$

Bernardo, L., C. Morcia, P. Carletti, R. Ghizzoni, F. W. Badeck, F. Rizza, L. Lucini, and V. Terzi. 2017. Proteomic insight into the mitigation of wheat root drought stress by arbuscular mycorrhizae. Journal of Proteomics 169:21-32. doi: 10.1016/j.jprot.2017.03.024 
Berruti, A., E. Lumini, R. Balestrini, and V. Bianciotto. 2015. Arbuscular mycorrhizal fungi as natural biofertilizers: let's benefit from past successes. Frontiers in Microbiology 6(1559). doi: 10.3389/fmicb.2015.01559

Birhane, E., F. J. Sterck, M. Fetene, F. Bongers, and T. W. Kuyper. 2012. Arbuscular mycorrhizal fungi enhance photosynthesis, water use efficiency, and growth of frankincense seedlings under pulsed water availability conditions. Oecologia 169(4):895904. doi: 10.1007/s00442-012-2258-3

Bowman, J. P., S. A. McCammon, M. V. Brown, D. S. Nichols, and T. A. McMeekin. 1997. Diversity and association of psychrophilic bacteria in Antarctic sea ice. Applied and Environmental Microbiology 63(8):3068-3078.

Campanelli, A., C. Ruta, G. De Mastro, and I. Morone-Fortunato. 2013. The role of arbuscular mycorrhizal fungi in alleviating salt stress in Medicago sativa L. var. icon. Symbiosis 59(2):65-76. doi: 10.1007/s13199-012-0191-1

Cartmill, A. D., A. Alarcón, and L. A., Valdez-Aguilar. 2007. Arbuscular mycorrhizal fungi enhance tolerance of Rosa multiflora cv. Burr to bicarbonate in irrigation water. Journal of Plant Nutrition 30(9):1517-1540. doi: 10.1080/01904160701556802

Charest, C., Y. Dalpé, and A. Brown. 1993. The effect of vesicular-arbuscular mycorrhizae and chilling on two hybrids of Zea mays L. Mycorrhiza 4(2):89-92. doi: 10.1007/BF00204064

Chen, S., W. Jin, A. Liu, S. Zhang, D. Liu, F. Wang, X. Lin, and C. He. 2013. Arbuscular mycorrhizal fungi (AMF) increase growth and secondary metabolism in cucumber subjected to low temperature stress. Scientia Horticulturae 160:222-229. doi: 10.1016/j.scienta.2013.05.039

Chen, X., F. Song, F. Liu, C. Tian, S. Liu, H. Xu, and X. Zhu. 2014. Effect of different arbuscular mycorrhizal fungi on growth and physiology of maize at ambient and low temperature regimes. The Scientific World Journal 2014:1-7. doi: 10.1155/2014/956141

Chu, X. T. 2016. Effect of arbuscular mycorrhizal fungi inoculation on cold stress-induced oxidative damage in leaves of Elymus nutans Griseb. South African Journal of Botany 104:21-29. doi: 10.1016/j.sajb.2015.10.001

Classen, A. T., M. K. Sundqvist, J. A. Henning, G. S. Newman, J. A. M. Moore, M. A. Cregger, L. C. Moorhead, and C. M. Patterson. 2015. Direct and indirect effects of climate change on soil microbial and soil microbial-plant interactions: What lies ahead? Ecosphere 6(8):1-21. doi: 10.1890/ES15-00217.1 
da-Silva, J. R., A. Alexandre, C. Brígido, and S. Oliveira. 2017. Can stress response genes be used to improve the symbiotic performance of rhizobia? AIMS Microbiology 3(3):365382. doi: 10.3934/microbiol.2017.3.365

Drouin, P., D. Prévost, and H. Antoun. 2000. Physiological adaptation to low temperatures of strains of Rhizobium leguminosarum bv. viciae associated with Lathyrus spp.1. FEMS Microbiology Ecology 32(2): 111-120. doi: 10.1111/j.1574-6941.2000.tb00705.x

Dsouza, M., M. W. Taylor, S. J. Turner, and J. Aislabie. 2014. Genome-based comparative analyses of antarctic and temperate species of Paenibacillus. PLOS ONE 9(10):e108009. doi: 10.1371/journal.pone.0108009

Duperron, S. 2017. 1 - The Concept of Symbiosis, from Past to Present, Microbial Symbioses. Elsevier, pp. 1-17. doi: 10.1016/B978-1-78548-220-5.50001-5

Eisenhauer, N., A. Lanoue, T. Strecker, S. Scheu, K. Steinauer, M. P. Thakur, and L. Mommer. 2017. Root biomass and exudates link plant diversity with soil bacterial and fungal biomass. Plant, Cell \& Environment 7(44641). doi: 10.1038/srep44641

Estrada, B., R. Aroca, F. J. M. Maathuis, J. M. Barea, and J. M. Ruiz-Lozano. 2013. Arbuscular mycorrhizal fungi native from a Mediterranean saline area enhance maize tolerance to salinity through improved ion homeostasis. Plant, Cell \& Environment 36(10):1771-1782. doi: 10.1111/pce.12082

Evelin, H., and R. Kapoor. 2014. Arbuscular mycorrhizal symbiosis modulates antioxidant response in salt-stressed Trigonella foenum-graecum plants. Mycorrhiza 24(3):197-208. doi: 10.1007/s00572-013-0529-4

Evelin, H., R. Kapoor, and B. Giri. 2009. Arbuscular mycorrhizal fungi in alleviation of salt stress: a review. Annals of Botany 104(7):1263-1280. doi: 10.1093/aob/mcp251

Fan, Q.-J., and J.-H., Liu. 2011. Colonization with arbuscular mycorrhizal fungus affects growth, drought tolerance and expression of stress-responsive genes in Poncirus trifoliata. Acta Physiologiae Plantarum, 33(4):1533-1542. doi: 10.1007/s11738-011-0789-6

Fernandez, O., A. Theocharis, S. Bordiec, R. Feil, L. Jacquens, C. Clément, F. Fontaine, and E. A. Barka. 2012. Burkholderia phytofirmans PsJN acclimates grapevine to cold by modulating carbohydrate metabolism. Molecular Plant-Microbe Interactions 25(4):496504. doi: 10.1094/MPMI-09-11-0245

Fu, Y., H. Gao, H. Li, Y. Qin, W. Tang, J. Lu, M. Li, L., Shao, and H. Liu. 2017. Change of growth promotion and disease resistant of wheat seedling by application of biocontrol bacterium Pseudochrobactrum kiredjianiae A4 under simulated microgravity. Acta Astronautica 139(Supplement C):222-227. doi: 10.1016/j.actaastro.2017.06.022 
Gavito, M. E., and C. Azcón-Aguilar. 2012. Temperature stress in arbuscular mycorrhizal fungi: a test for adaptation to soil temperature in three isolates of Funneliformis mosseae from different climates. Agricultural and Food Science 21(1):2-11. doi: 10.23986/afsci.4994

Ghobakhlou, A., S. Laberge, H. Antoun, D. S. Wishart, J. Xia, R. Krishnamurthy, and R. Mandal. 2013. Metabolomic analysis of cold acclimation of arctic Mesorhizobium sp. Strain N33. PLoS ONE 8(12):e84801. doi: 10.1371/journal.pone.0084801

González, M. B. R., and J. Gonzalez-López. 2013. Beneficial plant-microbial interactions: ecology and applications. CRC press. doi: 10.1201/b15251

Gougoulias, C., J. M. Clark, and L. J. Shaw. 2014. The role of soil microbes in the global carbon cycle: tracking the below-ground microbial processing of plant-derived carbon for manipulating carbon dynamics in agricultural systems. Journal of the Science of Food and Agriculture 94(12):2362-2371. doi: 10.1002/jsfa.6577

Gpey, W. E. 1991. Influence of temperature on colonization of spring barleys by vesicular arbuscular mycorrhizal fungi. Plant and Soil 137(2):181-190. doi: 10.1007/BF00011196

Graham, P. H. 1992. Stress tolerance in Rhizobium and Bradyrhizobium, and nodulation under adverse soil conditions. Canadian Journal of Microbiology 38(6):475-484. doi: $10.1139 / \mathrm{m} 92-079$

Gupta, V. 2011. Microbes and Soil Structure, In: Encyclopedia of Agrophysics, eds J. Gliński, J. Horabik, J. Lipiec, 470-472. Springer Netherlands, Dordrecht. doi: 10.1007/978-90-481-3585-1_91

Hart, M. M., and J. N. Klironomos. 2003. Diversity of Arbuscular Mycorrhizal Fungi and Ecosystem Functioning, In: Mycorrhizal Ecology, M. G. A. van der Heijden, I. R. Sanders, 225-242. Springer Berlin Heidelberg, Berlin, Heidelberg. doi: 10.1007/978-3-540-38364-2_9

Hayat, W., H. Aman, U. Irshad, M. Azeem, A. Iqbal, and R. Nazir. 2017. Analysis of ecological attributes of bacterial phosphorus solubilizers, native to pine forests of Lower Himalaya. Applied Soil Ecology 112:51-59. doi: 10.1016/j.apsoil.2016.11.004

Howieson, J., and R. Ballard. 2004. Optimising the legume symbiosis in stressful and competitive environments within southern Australia—some contemporary thoughts. Soil Biology and Biochemistry 36(8):1261-1273. doi: 10.1016/j.soilbio.2004.04.008

Hu, W., H. Zhang, H. Chen, and M. Tang. 2017. Arbuscular mycorrhizas influence Lycium barbarum tolerance of water stress in a hot environment. Mycorrhiza 27(5):451-463. doi: $10.1007 / \mathrm{s} 00572-017-0765-0$ 
Janczarek, M., K. Rachwał, and A. Turska-Szewczuk. 2017. A mutation in pssE affects exopolysaccharide synthesis by Rhizobium leguminosarum bv. trifolii, its surface properties, and symbiosis with clover. Plant and Soil 417(1):331-347. doi: 10.1007/s11104-017-3262-5

Johnson, N. C., J. H. Graham, and F. A. Smith. 1997. Functioning of mycorrhizal associations along the mutualism-parasitism continuum. New Phytologist 135(4):575-585. doi: 10.1046/j.1469-8137.1997.00729.x

Junge, K., B. Christner, J. T. Staley. 2011. Diversity of Psychrophilic Bacteria from Sea Ice and Glacial Ice Communities, In: Extremophiles Handbook. ed. K. Horikoshi, 793-815. Springer Japan, Tokyo. doi: 10.1007/978-4-431-53898-1_39

Kang, S. W., B. Y. Jeon, T. S. Hwang, and D. H. Park. 2009. Symbiotic relationship between Microbacterium sp. SK0812 and Candida tropicalis SK090404. The Journal of Microbiology 47(6):721-727. doi: 10.1007/s12275-009-0146-2

Keto-Timonen, R., N. Hietala, E. Palonen, A. Hakakorpi, M. Lindström, and H. Korkeala. 2016. Cold shock proteins: a minireview with special emphasis on csp-family of enteropathogenic Yersinia. Frontiers in Microbiology 7(1151). doi: 10.3389/fmicb.2016.01151

Kim, K. Y., Y. S. Cho, B. K. Sohn, R. D. Park, , J. H. Shim, S. J. Jung, Y. W. Kim, and K. Y. Seong. 2002. Cold-storage of mixed inoculum of Glomus intraradices enhances root colonization, phosphorus status and growth of hot pepper. Plant and Soil 238(2):267-272. doi: $10.1023 / \mathrm{A}: 1014474617170$

Kishitani, S., K. Watanabe, S. Yasuda, K. Arakawa, and T. Takabe. 1994. Accumulation of glycinebetaine during cold acclimation and freezing tolerance in leaves of winter and spring barley plants. Plant, Cell \& Environment 17(1):89-95. doi: 10.1111/j.1365-3040.1994.tb00269.x

Kwon, S. J., S. I. Kwon, M. S. Bae, E. J. Cho, and O. K. Park, 2007. Role of the methionine sulfoxide reductase MsrB3 in cold acclimation in Arabidopsis. Plant and Cell Physiology 48(12):1713-1723. doi: 10.1093/pcp/pcm143

Kytöviita, M.-M. 2005. Asymmetric symbiont adaptation to Arctic conditions could explain why high Arctic plants are non-mycorrhizal. FEMS Microbiology Ecology 53(1):27-32. doi: 10.1016/j.femsec.2004.09.014

Laforest-Lapointe, I., A. Paquette, C. Messier, and S. W. Kembel. 2017. Leaf bacterial diversity mediates plant diversity and ecosystem function relationships. Nature 546(7656):145-147. doi: 10.1038/nature22399 
Laguerre, G., P. van Berkum, N. Amarger, and D. Prévost. 1997. Genetic diversity of rhizobial symbionts isolated from legume species within the genera Astragalus, Oxytropis, and Onobrychis. Applied and Environmental Microbiology 63(12):4748-4758.

Laranjo, M., and S. Oliveira. 2011. Tolerance of Mesorhizobium type strains to different environmental stresses. Antonie van Leeuwenhoek 99(3):651-662.

doi: 10.1007/s10482-010-9539-9

Larrainzar, E., and S. Wienkoop. 2017. A proteomic view on the role of legume symbiotic interactions. Frontiers in Plant Science 8(1267). doi: 10.3389/fpls.2017.01267

Lekberg, Y., and R. T. Koide. 2008. Effect of soil moisture and temperature during fallow on survival of contrasting isolates of arbuscular mycorrhizal fungi. Botany 86(10):1117-1124. doi: 10.1139/B08-077

Li, H.-Y., M. Shen, Z.-P. Zhou, T. Li, Y.-I. Wei, and L.-b. Lin. 2012. Diversity and cold adaptation of endophytic fungi from five dominant plant species collected from the Baima Snow Mountain, Southwest China. Fungal Diversity 54(1):79-86.

doi: 10.1007/s13225-012-0153-1

Lipson, D. A., R. F. Wilson, and W. C. Oechel. 2005. Effects of elevated atmospheric $\mathrm{CO}_{2}$ on soil microbial biomass, activity, and diversity in a chaparral ecosystem. Applied and Environmental Microbiology 71(12):8573-8580. doi: 10.1128/aem.71.12.8573-8580.2005

Liu, A., S. Chen, R. Chang, D. Liu, H. Chen, G. J. Ahammed, X. Lin, and C. He. 2014. Arbuscular mycorrhizae improve low temperature tolerance in cucumber via alterations in $\mathrm{H}_{2} \mathrm{O}_{2}$ accumulation and ATPase activity. Journal of Plant Research 127(6):775-785. doi: $10.1007 / \mathrm{s} 10265-014-0657-8$

Liu, M.-Z., and C. P. Osborne. 2008. Leaf cold acclimation and freezing injury in $\mathrm{C}_{3}$ and $\mathrm{C}_{4}$ grasses of the Mongolian Plateau. Journal of Experimental Botany 59(15):4161-4170. doi: $10.1093 / \mathrm{jxb} / \mathrm{ern} 257$

Mageswari, A., P. Subramanian, R. Srinivasan, S. Karthikeyan, and K. M. Gothandam. 2015. Astaxanthin from psychrotrophic Sphingomonas faeni exhibits antagonism against foodspoilage bacteria at low temperatures. Microbiological Research 179:38-44. doi: 10.1016/j.micres.2015.06.010

Maggi, O., S. Tosi, M. Angelova, E. Lagostina, A. A. Fabbri, L. Pecoraro, E. Altobelli, A. M. Picco, E. Savino, E. Branda, B. Turchetti, M. Zotti, A. Vizzini, and P. Buzzini. 2013. Adaptation of fungi, including yeasts, to cold environments. Plant Biosystems - An International Journal Dealing with all Aspects of Plant Biology 147(1):247-258. doi: 10.1080/11263504.2012.753135 
Maksimov, E. G., K. S. Mironov, M. S. Trofimova, N. L. Nechaeva, D. A. Todorenko, K. E. Klementiev, G. V. Tsoraev, E. V. Tyutyaev, A. A. Zorina, P. V. Feduraev, S. I.

Allakhverdiev, V. Z. Paschenko, and D. A. Los. 2017. Membrane fluidity controls redoxregulated cold stress responses in cyanobacteria. Photosynthesis Research 133(1):215-223. doi: $10.1007 / \mathrm{s} 11120-017-0337-3$

Margesin, R., V. Fauster, and P. A. Fonteyne. 2005. Characterization of cold-active pectate lyases from psychrophilic Mrakia frigida. Letters in Applied Microbiology 40(6):453-459. doi: 10.1111/j.1472-765X.2005.01704.X

Medina, A., and R. Azcón. 2010. Effectiveness of the application of arbuscular mycorrhiza fungi and organic amendments to improve soil quality and plant performance under stress conditions. Journal of Soil Science and Plant Nutrition 10(3):354-372. doi: 10.4067/S0718-95162010000100009

Mei, Y.-Z., P.-W. Huang, Y. Liu, W. He, and W.-W. Fang. 2016. Cold stress promoting a psychrotolerant bacterium Pseudomonas fragi P121 producing trehaloase. World Journal of Microbiology and Biotechnology 32(8):1-9. doi: 10.1007/s11274-016-2097-1

Michaux, C., E. Holmqvist, E. Vasicek, M. Sharan, L. Barquist, A. J. Westermann, J. S. Gunn, J. and Vogel. 2017. RNA target profiles direct the discovery of virulence functions for the cold-shock proteins CspC and CspE. Proceedings of the National Academy of Sciences 114(26):6824-6829. doi: 10.1073/pnas.1620772114

Millar, N. S., and Bennett, A. E. 2016. Stressed out symbiotes: hypotheses for the influence of abiotic stress on arbuscular mycorrhizal fungi. Oecologia 182(3):625-641. doi: $10.1007 / \mathrm{s} 00442-016-3673-7$

Miltner, A., H.-H. Richnow, F.-D. Kopinke, and M. Kästner. 2004. Assimilation of $\mathrm{CO}_{2}$ by soil microorganisms and transformation into soil organic matter. Organic Geochemistry 35(9):1015-1024. doi: 10.1016/j.orggeochem.2004.05.001

Mishra, P. K. 2011. Bioassociative effect of cold tolerant Pseudomonas spp. and Rhizobium leguminosarum-PR1 on iron acquisition, nutrient uptake and growth of lentil (Lens culinaris L.). European Journal of Soil Biology 47(1):35-43.

doi: 10.1016/j.ejsobi.2010.11.005

Mishra, P. K., S. C. Bisht, J. K. Bisht, and J. C. Bhatt. 2012. Cold-Tolerant PGPRs as Bioinoculants for Stress Management, In: Bacteria in Agrobiology: Stress Management, ed. D. K. Maheshwari, 95-118. Springer Berlin Heidelberg, Berlin, Heidelberg. doi: 10.1007/978-3-642-23465-1_6 
Mishra, P. K., S. C. Bisht, P. Ruwari, G. Selvakumar, G. K. Joshi, J. K. Bisht, J. C. Bhatt, and H. S. Gupta. 2011. Alleviation of cold stress in inoculated wheat (Triticum aestivum L.) seedlings with psychrotolerant Pseudomonads from NW Himalayas. Archives of Microbiology 193(7):497-513. doi: 10.1007/s00203-011-0693-х

Morita, R. Y. 1975. Psychrophilic bacteria. Bacteriological Reviews 39(2):144-167.

Ouellet, F., and J.-B. Charron. 2013. Cold acclimation and freezing tolerance in plants, eLS. John Wiley \& Sons, Ltd. doi: 10.1002/9780470015902.a0020093.pub2

Paço, A., C. Brígido, A. Alexandre, P. F. Mateos, and S. Oliveira. 2016. The symbiotic performance of Chickpea rhizobia can be improved by additional copies of the $\operatorname{clp} B$ chaperone gene. PLOS ONE 11(2):e0148221. doi: 10.1371/journal.pone.0148221

Padbhushan, R., and D. Kumar. 2015. Yield and nutrient uptake of green gram (Vigna radiata L.) as influenced by boron application in boron-deficient calcareous soils of punjab. Communications in Soil Science and Plant Analysis 46(7):908-923. doi: 10.1080/00103624.2015.1018520

Panadero, J., C. Pallotti, S. Rodríguez-Vargas, F. Randez-Gil, and J. A. Prieto. 2006. A downshift in temperature activates the high osmolarity glycerol (HOG) pathway, which determines freeze tolerance in Saccharomyces cerevisiae. Journal of Biological Chemistry 281(8):4638-4645. doi: 10.1074/jbc.M512736200

Pistelli, L., V. Ulivieri, S. Giovanelli, L. Avio, M. Giovannetti, and L. Pistelli. 2017. Arbuscular mycorrhizal fungi alter the content and composition of secondary metabolites in Bituminaria bituminosa L. Plant Biology 19(6):926-933. doi: 10.1111/plb.12608

Poltronieri, P., V. Mezzolla, and O. F. D’Urso. 2014. Bacterial small RNAs and their role in stress tolerance and adaptation to environment. Research in Cell Biology 2(1):8-16. doi: 10.5923/j.cellbiology.20140201.02

Prévost, D., P. Drouin, S. Laberge, A. Bertrand, J. Cloutier, and G. Lévesque. 2003. Coldadapted rhizobia for nitrogen fixation in temperate regions. Canadian Journal of Botany 81(12):1153-1161. doi: 10.1139/b03-113

Qin, Y., Y. Fu, W. Kang, H. Li, H. Gao, K. S. Vitalievitch, and H. Liu. 2017. Isolation and identification of a cold-adapted bacterium and its characterization for biocontrol and plant growth-promoting activity. Ecological Engineering 105(Supplement C):362-369. doi: https://doi.org/10.1016/j.ecoleng.2017.04.045

Quiroga, G., G. Erice, R. Aroca, F. Chaumont, and J. M. Ruiz-Lozano. 2017. Enhanced drought stress tolerance by the arbuscular mycorrhizal symbiosis in a drought-sensitive 
maize cultivar is related to a broader and differential regulation of host plant aquaporins than in a drought-tolerant cultivar. Frontiers in Plant Science 8(1056):1-15. doi: $10.3389 /$ fpls.2017.01056

Rahimzadeh, S., and A. R. Pirzad. 2017. Microorganisms (AMF and PSB) interaction on linseed productivity under water-deficit condition. International Journal of Plant Production 11(2):259-274. doi: 10.22069/ijpp.2017.3423

Rayirath, P., B. Benkel, D. Mark Hodges, P. Allan-Wojtas, S. MacKinnon, A. T. Critchley, and B. Prithiviraj. 2009. Lipophilic components of the brown seaweed, Ascophyllum nodosum, enhance freezing tolerance in Arabidopsis thaliana. Planta 230(1):135-147. doi: $10.1007 / \mathrm{s} 00425-009-0920-8$

Rinu, K., and A. Pandey. 2010. Temperature-dependent phosphate solubilization by cold- and pH-tolerant species of Aspergillus isolated from Himalayan soil. Mycoscience 51(4):263271. doi: 10.1007/S10267-010-0036-9

Robledo, M., A. Peregrina, V. Millán, N. I. García-Tomsig, O. Torres-Quesada, P. F. Mateos, A. Becker, and J. I. Jiménez-Zurdo. 2017. A conserved $\alpha$-proteobacterial small RNA contributes to osmoadaptation and symbiotic efficiency of rhizobia on legume roots. Environmental Microbiology 19(7):2661-2680. doi: 10.1111/1462-2920.13757

Sardesai, N., and C. R. Babu. 2001. Poly- $\beta$-hydroxybutyrate metabolism is affected by changes in respiratory enzymatic activities due to cold stress in two psychrotrophic strains of Rhizobium. Current Microbiology, 42(1):53-58. doi: 10.1007/s002840010178

Schreiner, R. P., J. M. Tarara, and R. P. Smithyman. 2007. Deficit irrigation promotes arbuscular colonization of fine roots by mycorrhizal fungi in grapevines (Vitis vinifera L.) in an arid climate. Mycorrhiza 17(7):551-562. doi: 10.1007/s00572-007-0128-3

Schüßler, A., D. Schwarzott, and C. Walker. 2001. A new fungal phylum, the Glomeromycota: phylogeny and evolution. Mycological Research 105(12):1413-1421. doi: $10.1017 / \mathrm{S} 0953756201005196$

Selvakumar, G., K. Kim, C. C. Shagol, M. M. Joe, and T. Sa. 2017. Spore associated bacteria of arbuscular mycorrhizal fungi improve maize tolerance to salinity by reducing ethylene stress level. Plant Growth Regulation 81(1):159-165. doi: 10.1007/s10725-016-0184-9

Selvakumar, G., S. Kundu, P. Joshi, S. Nazim, A. D. Gupta, P. K. Mishra, and H. S. Gupta. 2008. Characterization of a cold-tolerant plant growth-promoting bacterium Pantoea dispersa 1A isolated from a sub-alpine soil in the North Western Indian Himalayas. World Journal of Microbiology and Biotechnology 24(7):955-960.

doi: 10.1007/s11274-007-9558-5 
Sessitsch, A., A. Weilharter, M. H. Gerzabek, H. Kirchmann, and E. Kandeler. 2001.

Microbial population structures in soil particle size fractions of a long-term fertilizer field experiment. Applied and Environmental Microbiology 67(9), 4215-4224.

doi: 10.1128/aem.67.9.4215-4224.2001

Shahzad, R., A. L. Khan, S. Bilal, M. Waqas, S.-M. Kang, and I.-J. Lee. 2017. Inoculation of abscisic acid-producing endophytic bacteria enhances salinity stress tolerance in Oryza sativa. Environmental and Experimental Botany 136:68-77.

doi: 10.1016/j.envexpbot.2017.01.010

Sharma, C., R. K. Gupta, R. K. Pathak, and K. K. Choudhary. 2013. Seasonal colonization of arbuscular mycorrhiza fungi in the roots of Camellia sinensis (tea) in different tea gardens of India. ISRN Biodiversity 2013:1-6. doi: 10.1155/2013/593087

Shi, S.-M., K. Chen, Y. Gao, B. Liu, X.-H. Yang, X.-Z. Huang, G.-X. Liu, L.-Q. Zhu, and X.H. He. 2016. Arbuscular mycorrhizal fungus species dependency governs better plant physiological characteristics and leaf quality of mulberry (Morus alba L.) seedlings. Frontiers in Microbiology 7(1030). doi: 10.3389/fmicb.2016.01030

Shires, K., and L. Steyn. 2001. The cold-shock stress response in Mycobacterium smegmatis induces the expression of a histone-like protein. Molecular Microbiology 39(4):994-1009. doi: 10.1046/j.1365-2958.2001.02291.x

Shtark, O. Y., A. Y. Borisov, V. A. Zhukov, T. A. Nemankin, and I. A. Tikhonovich. 2012. Multicomponent symbiosis of legumes with beneficial soil microorganisms: Genetic and evolutionary bases of application in sustainable crop production. Russian Journal of Genetics: Applied Research 2(2):177-189. doi: 10.1134/S2079059712020116

Shtark, O. Y., V. A. Zhukov, A. S. Sulima, R. Singh, T. S. Naumkina, G. A. Akhtemova, and A. Y. Borisov, 2015. Prospects for the use of multi-component symbiotic systems of the Legumes. EcoGen 13(1):33-46. doi: 10.17816/ecogen13133-46

Srinivasan, R., A. Mageswari, P. Subramanian, V. K. Maurya, C. Sugnathi, C. Amballa, T. Sa, and K. Gothandam, 2017. Exogenous expression of ACC deaminase gene in psychrotolerant bacteria alleviates chilling stress and promotes plant growth in millets under chilling conditions. Indian Journal of Experimental Biology 55(7):463-468.

Strimbeck, G. R., P. G. Schaberg, C. G. Fossdal, W. P. Schröder, and T. D., Kjellsen. 2015. Extreme low temperature tolerance in woody plants. Frontiers in Plant Science 6(884). doi: 10.3389/fpls.2015.00884

Su, F., C. Jacquard, S. Villaume, J. Michel, F. Rabenoelina, C. Clément, E. A. Barka, S. Dhondt-Cordelier, and N. Vaillant-Gaveau. 2015. Burkholderia phytofirmans PsJN 
reduces impact of freezing temperatures on photosynthesis in Arabidopsis thaliana. Frontiers in Plant Science 6(810). doi: 10.3389/fpls.2015.00810

Subramanian, P., K. Kim, R. Krishnamoorthy, A. Mageswari, G. Selvakumar, and T. Sa, 2016. Cold stress tolerance in psychrotolerant soil bacteria and their conferred chilling resistance in tomato (Solanum lycopersicum Mill.) under low temperatures. PLOS ONE 11(8):e0161592. doi: 10.1371/journal.pone.0161592

Subramanian, P., R. Krishnamoorthy, M. Chanratana, K. Kim, and T. Sa. 2015. Expression of an exogenous 1-aminocyclopropane-1-carboxylate deaminase gene in psychrotolerant bacteria modulates ethylene metabolism and cold induced genes in tomato under chilling stress. Plant Physiology and Biochemistry 89:18-23. doi: 10.1016/j.plaphy.2015.02.003

Sun, H., M. Santalahti, J. Pumpanen, K. Koster, F. Berninger, T. Raffaello, A. Jumpponen, F. O. Asiegbu, and J. Heinonsalo. 2015. Fungal community shifts in structure and function across a boreal forest fire chronosequence. Applied and Environmental Microbiology 81(22):7869-7880. doi: 10.1128/aem.02063-15

Suyal, D. C., S. Kumar, A. Yadav, Y. Shouche, and R. Goel. 2017. Cold stress and nitrogen deficiency affected protein expression of psychrotrophic dyadobacter psychrophilus B2 and Pseudomonas jessenii MP1. Frontiers in Microbiology 8(430). doi: 10.3389/fmicb.2017.00430

Tardy, V., O. Mathieu, J. Leveque, S. Terrat, A. Chabbi, P. Lemanceau, L. Ranjard, and P. A. Maron. 2014. Stability of soil microbial structure and activity depends on microbial diversity. Environmental Microbiology Reports 6(2):173-183. doi: 10.1111/1758-2229.12126

Theocharis, A., S. Bordiec, O. Fernandez, S. Paquis, S. Dhondt-Cordelier, F. Baillieul, C. Clément, and E. A. Barka. 2011. Burkholderia phytofirmans PsJN primes Vitis vinifera L. and confers a better tolerance to low nonfreezing temperatures. Molecular Plant-Microbe Interactions 25(2):241-249. doi: 10.1094/MPMI-05-11-0124

Thomas-Hall, S. R., B. Turchetti, P. Buzzini, E. Branda, T. Boekhout, B. Theelen, and K. Watson. 2010. Cold-adapted yeasts from Antarctica and the Italian Alps-description of three novel species: Mrakia robertii sp. nov., Mrakia blollopis sp. nov. and Mrakiella niccombsii sp. nov. Extremophiles 14(1):47-59. doi: 10.1007/s00792-009-0286-7

Thomashow, M. F. 1999. Plant cold acclimation: freezing tolerance genes and regulatory mechanisms. Annual Review of Plant Physiology and Plant Molecular Biology 50(1):571599. doi: 10.1146/annurev.arplant.50.1.571 
Tiwari, S., V. Prasad, P. S. Chauhan, and C. Lata. 2017. Bacillus amyloliquefaciens confers tolerance to various abiotic stresses and modulates plant response to phytohormones through osmoprotection and gene expression regulation in rice. Frontiers in Plant Science 8(1510). doi: 10.3389/fpls.2017.01510

Tsuji, M. 2016. Cold-stress responses in the Antarctic basidiomycetous yeast Mrakia blollopis. Royal Society Open Science 3(7):160106. doi: 10.1098/rsos.160106

Urcelay, C., and S. Díaz. 2003. The mycorrhizal dependence of subordinates determines the effect of arbuscular mycorrhizal fungi on plant diversity. Ecology Letters 6(5):388-391. doi: 10.1046/j.1461-0248.2003.00444.x

Van Der Heijden, M. G., S. De Bruin, L. Luckerhoff, R. S. Van Logtestijn, and K. Schlaeppi. 2016. A widespread plant-fungal-bacterial symbiosis promotes plant biodiversity, plant nutrition and seedling recruitment. The ISME Journal 10(2):389-399.

doi: 10.1038/ismej.2015.120

Van der Heijden, M. G., J. N. Klironomos, M. Ursic, and P. Moutoglis. 1998. Mycorrhizal fungal diversity determines plant biodiversity, ecosystem variability and productivity. Nature 396(6706), 69-72. doi: $10.1038 / 23932$

Van Der Heijden, M. G. A., R. D. Bardgett, and N. M. Van Straalen. 2008. The unseen majority: soil microbes as drivers of plant diversity and productivity in terrestrial ecosystems. Ecology Letters 11(3):296-310. doi: 10.1111/j.1461-0248.2007.01139.x

Varga, S., and M.-M. Kytöviita. 2016. Faster acquisition of symbiotic partner by common mycorrhizal networks in early plant life stage. Ecosphere 7(1):e01222. doi: $10.1002 /$ ecs2.1222

Verma, P., A. N. Yadav, S. Kazy, B. Sing, V. S. Chauhan, and A. Suman. 2015. Plant growth promotion and mitigation of cold stress in inoculated wheat (Triticum aestivum L.) by Ksolubilizing psychrotolerant Methylobacterium phyllosphaerae strain IARI-HHS2-67, International Conference on "Low Temperature Science and Biotechnological Advances", , National Bureau of Plant Genetic Resources (NBPGR-ICAR) Pusa Campus, New Delhi110012. doi:10.13140/RG.2.1.4885.1362

Wachowska, U., W. Irzykowski, M. Jędryczka, A. D. Stasiulewicz-Paluch, and K. Głowacka. 2013. Biological control of winter wheat pathogens with the use of antagonistic Sphingomonas bacteria under greenhouse conditions. Biocontrol Science and Technology 23(10):1110-1122. doi: 10.1080/09583157.2013.812185 
Wang, B., D. Funakoshi, Y. Dalpé, and C. Hamel. 2002. Phosphorus-32 absorption and translocation to host plants by arbuscular mycorrhizal fungi at low root-zone temperature. Mycorrhiza 12(2):93-96. doi: 10.1007/s00572-001-0150-9

Warren, G. J. 1998. Cold stress: Manipulating freezing tolerance in plants. Current Biology 8(15):514-516. doi: 10.1016/S0960-9822(07)00335-1

Witter, L. D. 1961. Psychrophilic bacteria—a review. Journal of Dairy Science 44(6):9831015. doi: 10.3168/jds.S0022-0302(61)89851-2

Wright, S. F., J. L. Starr, and I. C. Paltineanu. 1999. Changes in aggregate stability and concentration of glomalin during tillage management transition. Soil Science Society of America Journal 63(6):1825-1829. doi: 10.2136/sssaj1999.6361825x

Xiaochuang, C., Z. Chu, Z. Lianfeng, Z. Junhua, S. Hussain, W. Lianghuan, and J. Qianyu. 2017. Glycine increases cold tolerance in rice via the regulation of $\mathrm{N}$ uptake, physiological characteristics, and photosynthesis. Plant Physiology and Biochemistry 112:251-260. doi: 10.1016/j.plaphy.2017.01.008

Yadav, A. N., P. Verma, V. Kumar, S. G. Sachan, and A. K. Saxena. 2017. Extreme cold environments: a suitable niche for selection of novel psychrotrophic microbes for biotechnological applications. Advances in Biotechnology and Microbiology, 2(2):555584. doi: 10.19080/AIBM.2017.02.555584

Yu, T.-F., Z.-S. Xu, J.-K. Guo, Y.-X. Wang, B. Abernathy, J.-D. Fu, X. Chen, Y.-B. Zhou, M. Chen, X.-G. Ye, and Y.-Z. Ma. 2017. Improved drought tolerance in wheat plants overexpressing a synthetic bacterial cold shock protein gene $S e C s p A$. 7(44050). doi: $10.1038 /$ srep44050

Zaidi, A., and S. Khan. 2005. Interactive effect of rhizotrophic microorganisms on growth, yield, and nutrient uptake of wheat. Journal of Plant Nutrition 28(12):2079-2092. doi: 10.1080/01904160500320897

Zhang, W., H. Zhang, L. Ning, B. Li, and M. Bao. 2016. Quantitative proteomic analysis provides novel insights into cold stress responses in petunia seedlings. Frontiers in Plant Science 7(136). doi: 10.3389/fpls.2016.00136

Zhang, Y., S. Dong, Q. Gao, S. Liu, H. Ganjurjav, X. Wang, X. Su, and X. Wu. 2017. Soil bacterial and fungal diversity differently correlated with soil biochemistry in alpine grassland ecosystems in response to environmental changes. Scientific Reports 7(43077). doi: $10.1038 /$ srep43077 
Zhang, Z., J. Zhang, and Y. Huang, 2014. Effects of arbuscular mycorrhizal fungi on the drought tolerance of Cyclobalanopsis glauca seedlings under greenhouse conditions. New Forests 45(4):545-556. doi: 10.1007/s11056-014-9417-9

Zhou, Z., H. Ma, K. Liang, G. Huang, and K. Pinyopusarerk. 2012. Improved tolerance of teak (Tectona grandis L.f.) seedlings to low-temperature stress by the combined effect of arbuscular mycorrhiza and paclobutrazol. Journal of Plant Growth Regulation 31(3):427435. doi: 10.1007/s00344-011-9252-6

Zhu, X.-C., F.-B. Song, and H.-W. Xu. 2010a. Arbuscular mycorrhizae improves low temperature stress in maize via alterations in host water status and photosynthesis. Plant and Soil 331(1):129-137. doi: 10.1007/s11104-009-0239-z

Zhu, X. C., F. B. Song, T. D. Liu, and S. Q. Liu. 2010b. Arbuscular mycorrhizae reducing water loss in maize plants under low temperature stress. Plant Signaling \& Behavior 5(5):591-593. doi: 10.4161/psb.11498

Zhu, X., F. Song, and F. Liu. 2016. Altered amino acid profile of arbuscular mycorrhizal maize plants under low temperature stress. Journal of Plant Nutrition and Soil Science 179(2):186-189. doi: 10.1002/jpln.201400165 
Table 1. Effects of plant-fungi symbiosis on plant tolerance to cold stress

\begin{tabular}{|c|c|c|c|c|}
\hline Fungi & Activity threshold & Host plant & Function & References \\
\hline Glomus mosseae & Active at $5{ }^{\circ} \mathrm{C}$. & Elymus nutans Griseb & $\begin{array}{l}\text { Enhanced tolerance to } 5{ }^{\circ} \mathrm{C} \text {; improved CHL } \\
\text { content, photosynthetic capacity, antioxidative } \\
\text { activity, soluble sugar and glutathione } \\
\text { accumulation. }\end{array}$ & (Chu 2016) \\
\hline $\begin{array}{l}\text { Glomus claroideum; } \\
\text { Claroideoglomus claroideum }\end{array}$ & Need to be tested. & No report was found. & $\begin{array}{l}\text { It is suggested that they may confer tolerance to } \\
\text { cold stress. }\end{array}$ & $\begin{array}{l}\text { (Cartmill et al. 2007; } \\
\text { Beltrano and Ronco, 2008; } \\
\text { Millar and Bennett 2016) }\end{array}$ \\
\hline Glomus geosporum & Need to be tested. & No report was found. & $\begin{array}{l}\text { It is suggested that it may confer tolerance to cold } \\
\text { stress. }\end{array}$ & (Evelin et al. 2009) \\
\hline Glomus viscosum & Need to be tested. & No report was found. & $\begin{array}{l}\text { It is suggested that it may confer tolerance to cold } \\
\text { stress. }\end{array}$ & (Campanelli et al. 2013) \\
\hline $\begin{array}{l}\text { Glomus etunicatum, } G . \\
\text { tortuosum, Acaulospora } \\
\text { scrobiculata, G. intraradices }\end{array}$ & $\begin{array}{l}\text { Colonization rate at } 25^{\circ} \mathrm{C} \\
\text { in maize:Glomus } \\
\text { etunicatum }>G \text {. } \\
\text { tortuosum }>\text { Acaulospora } \\
\text { scrobiculata }>G \text {. } \\
\text { intraradices } \\
\text { Colonization rate at } 15^{\circ} \mathrm{C} \text { : } \\
\text { G. intraradices }>A . \\
\text { scrobiculata }>G .\end{array}$ & Maize & $\begin{array}{l}\text { They may confer tolerance to cold stress, } \\
\text { depending on plant species and environmental } \\
\text { conditions and thus more studies are required; } \\
\text { they enhance plant antioxidant activity; Glomus } \\
\text { etunicatum enhanced maize tolerance to } 5^{\circ} \mathrm{C} \text {; } \\
\text { improved stomatal conductance, water status, } \\
\text { WUE, CHL content, and photosynthetic capacity }\end{array}$ & $\begin{array}{l}\text { (Wang et al. 2002; Evelin } \\
\text { and Kapoor 2014; Chen et } \\
\text { al. 2014; Zhu et al. 2010a; } \\
\text { Sharma et al. 2013) }\end{array}$ \\
\hline
\end{tabular}




\begin{tabular}{|c|c|c|c|c|}
\hline & $\begin{array}{l}\text { tortuosumand }>G \text {. } \\
\text { etunicatum } \\
\text { Threshold activity for } \\
\text { Glomusintraradices is } 10 \\
{ }^{\circ} \mathrm{C} \text { and } 5{ }^{\circ} \mathrm{C} \text { for Glomus } \\
\text { caledonium }\end{array}$ & & & \\
\hline G. albidum & Need to be tested. & No report was found. & $\begin{array}{l}\text { It is suggested that it may confer tolerance to cold } \\
\text { stress. }\end{array}$ & (Cartmill et al. 2007) \\
\hline G. diaphanum & Need to be tested. & No report was found. & $\begin{array}{l}\text { It is suggested that it may confer tolerance to cold } \\
\text { stress. }\end{array}$ & (Cartmill et al. 2007) \\
\hline $\begin{array}{l}\text { Antarctic strain of Geomyces } \\
\text { pannorum }\end{array}$ & $\begin{array}{l}\text { G. pannorum is a cold } \\
\text { tolerant strain; however, } \\
\text { its activity threshold need } \\
\text { to be tested. }\end{array}$ & $\begin{array}{l}\text { Its symbiotic relationship, } \\
\text { performance and } \\
\text { effectiveness need to be } \\
\text { tested. }\end{array}$ & $\begin{array}{l}\text { G. pannorum has high capacity for antioxidant } \\
\text { activity and phenolics biosynthesis under cold } \\
\text { condition and thus might improve plant tolerance } \\
\text { to cold stress }\end{array}$ & (Maggi et al. 2013) \\
\hline $\begin{array}{l}\text { Cladosporium } \\
\text { cladosporioides and } \\
\text { Scolecobasidium salinum, } \\
\text { Antarctic strain of Cadophora } \\
\text { fastigiate }\end{array}$ & $\begin{array}{l}\text { These strains are cold } \\
\text { tolerant; however, their } \\
\text { threshold activity need to } \\
\text { be tested. }\end{array}$ & $\begin{array}{l}\text { Their symbiotic relationship, } \\
\text { performance and } \\
\text { effectiveness need to be } \\
\text { tested. }\end{array}$ & $\begin{array}{l}\text { Have high levels of unsaturated fatty } \\
\text { acids/saturated fatty acids } \\
\text { at } 8{ }^{\circ} \mathrm{C} \text {. It is suggested that they may confer } \\
\text { tolerance to cold stress. }\end{array}$ & (Maggi et al. 2013) \\
\hline Funneliformis mosseae & $\begin{array}{l}\text { Sensitive to temperature } \\
\text { lower than } 15^{\circ} \mathrm{C} \text {. }\end{array}$ & & Non effective. & $\begin{array}{l}\text { (Gavito and Azcón- } \\
\text { Aguilar 2012) }\end{array}$ \\
\hline PBZ (80 ppm); & Effective at $5{ }^{\circ} \mathrm{C}$. & $\begin{array}{l}\text { Green bean (Phaseoluse } \\
\text { vulgaris L.) }\end{array}$ & $\begin{array}{l}\text { Enhanced tolerance to } 5^{\circ} \mathrm{C} \text {; enhanced antioxidant } \\
\text { activity. }\end{array}$ & $\begin{array}{l}\text { (Alizadeh Frutan et al. } \\
\text { 2016) }\end{array}$ \\
\hline
\end{tabular}




\begin{tabular}{|c|c|c|c|c|}
\hline $\begin{array}{l}\text { PBZ + Piriformospora } \\
\text { indica fungi }\end{array}$ & & & & \\
\hline $\begin{array}{l}\text { PBZ (50 ppm) and Glomus } \\
\text { versiforme fungi }\end{array}$ & $\begin{array}{l}\text { PBZ, G. versiforme and } \\
\text { their combination was } \\
\text { effective at } 0{ }^{\circ} \mathrm{C} \text { for } 12 \mathrm{~h} \text {; } \\
\text { the combination was } \\
\text { more effective than either } \\
\text { AMF or PBZ treatment. }\end{array}$ & Teak (Tectona grandis) & $\begin{array}{l}\text { Enhanced tolerance to } 0{ }^{\circ} \mathrm{C} \text { for } 12 \mathrm{~h} \text {; improved the } \\
\mathrm{CHL} \text { content, soluble protein content, and } \\
\text { antioxidant enzyme activities; } \mathrm{PBZ} \text { and AMF } \\
\text { could induce cytokinin biosynthesis and thus } \\
\text { hamper CHL degradation under cold stress. }\end{array}$ & (Zhou et al. 2012) \\
\hline $\begin{array}{l}\text { Acaulospora } \\
\text { scrobiculata and Rhizophagus } \\
\text { intraradices }\end{array}$ & Need to be tested. & No report was found. & $\begin{array}{l}\text { It is suggested that they may confer tolerance to } \\
\text { cold stress. }\end{array}$ & (Shi et al. 2016) \\
\hline $\begin{array}{l}\text { Cold adapted endophytic } \\
\text { fungi Penicillium, } \\
\text { Aspergillus, } \\
\text { Cephalosporium, Sirococcus }\end{array}$ & $\begin{array}{l}\text { Adapted to the cold } \\
\text { environment of Baima } \\
\text { Snow Mountain, } \\
\text { Southwest China; } \\
\text { however, their activity } \\
\text { threshold needs to be } \\
\text { tested. }\end{array}$ & More studies are required. & $\begin{array}{l}\text { It is suggested that they may confer tolerance to } \\
\text { cold stress. }\end{array}$ & (Li et al. 2012) \\
\hline
\end{tabular}




\begin{tabular}{|c|c|c|c|c|}
\hline $\begin{array}{l}\text { Ascomycetous fungi genera } \\
\text { including Embellisia, Phoma, } \\
\text { Geomyces, }\end{array}$ & $\begin{array}{l}\text { All genera can grow at } \\
-1{ }^{\circ} \mathrm{C}\end{array}$ & More studies are required. & $\begin{array}{l}\text { It is suggested that they may confer tolerance to } \\
\text { cold stress. }\end{array}$ & $\begin{array}{l}\text { (Margesin et al. 2005; } \\
\text { Thomas-Hall et al. 2010; } \\
\text { Maggi et al. 2013; Tsuji }\end{array}$ \\
\hline Tetracladium and Thelebolus & & & & 2016) \\
\hline \multicolumn{5}{|l|}{ Basidiomycetous } \\
\hline \multicolumn{5}{|l|}{ fungi including } \\
\hline \multicolumn{5}{|l|}{ Cryptococcus, Dioszegia, and } \\
\hline Leucosporidium fellii & & & & \\
\hline
\end{tabular}


Table 2. Effects of plant-bacteria symbiosis on plant tolerance to cold stress

\begin{tabular}{|c|c|c|c|c|}
\hline Bacteria & $\begin{array}{l}\text { Activity } \\
\text { threshold }\end{array}$ & Host plant & Function & Reference \\
\hline Burkholderia phytofirmans & $\begin{array}{l}\text { Remain } \\
\text { effective at } \\
-1{ }^{\circ} \mathrm{C} \text {. }\end{array}$ & Grapevine & Enhanced tolerance to $4{ }^{\circ} \mathrm{C}$. & $\begin{array}{l}\text { (Fernandez et al. } \\
\text { 2012; Theocharis } \\
\text { et al. 2011; Su et } \\
\text { al. 2015) }\end{array}$ \\
\hline $\begin{array}{l}\text { Psychrotolerant bacterium } \\
\text { Pseudomonasfragi } \mathrm{P} 121\end{array}$ & $\begin{array}{l}\text { Active at } 4-25 \\
{ }^{\circ} \mathrm{C} \text {. }\end{array}$ & No report was found. & $\begin{array}{l}\text { It is suggested that it may confer } \\
\text { tolerance to cold stress; It } \\
\text { produces trehalose to cope with } \\
\text { cold stress. }\end{array}$ & (Mei et al. 2016) \\
\hline $\begin{array}{l}\text { Pseudomonas migulae } \mathrm{S} 10724 ; \\
\text { P. palleroniana } \mathrm{N} 26 ; \\
\text { psychrotrophic diazotrophs } \\
\text { Dyadobacter psychrophilus } \mathrm{B} 2 ; \\
\text { Pseudomonas jessenii } \mathrm{MP} 1\end{array}$ & $\begin{array}{l}\text { Need to be } \\
\text { tested. }\end{array}$ & More studies are required. & $\begin{array}{l}\text { It is suggested that they may } \\
\text { confer tolerance to cold stress. }\end{array}$ & (Suyal et al. 2017) \\
\hline $\begin{array}{l}\text { Psychrotrophic cold-acclimated } \\
\text { RhizobiumATR1 }\end{array}$ & $\begin{array}{l}\text { Needs to be } \\
\text { tested. }\end{array}$ & More studies are required. & $\begin{array}{l}\text { It is suggested that it may confer } \\
\text { tolerance to cold stress. }\end{array}$ & $\begin{array}{l}\text { (Sardesai and } \\
\text { Babu 2001) }\end{array}$ \\
\hline $\begin{array}{l}\text { Psychrotolerant Pseudomonads } \\
\text { from north-western Indian } \\
\text { Himalayas }\end{array}$ & $\begin{array}{l}\text { Active at } 4-35 \\
{ }^{\circ} \mathrm{C} \text {. }\end{array}$ & Wheat & Enhanced tolerance to $4^{\circ} \mathrm{C}$. & $\begin{array}{l}\text { (Mishra et al. } \\
\text { 2011) }\end{array}$ \\
\hline
\end{tabular}




\begin{tabular}{|c|c|c|c|c|}
\hline $\begin{array}{l}\text { Pseudoalteromonas, } \\
\text { Psychrobacter, Halomonas, } \\
\text { Pseudomonas, Hyphomonas, } \\
\text { Sphingomonas, Arthrobacter, } \\
\text { Planococcus, and Halobacillus }\end{array}$ & $\begin{array}{l}\text { Active at } 4-15 \\
{ }^{\circ} \mathrm{C} \text {; tolerant to } \\
0{ }^{\circ} \mathrm{C} \text {. }\end{array}$ & $\begin{array}{l}\text { More studies are required to determine their } \\
\text { symbiotic relationships and effectiveness }\end{array}$ & $\begin{array}{l}\text { It is suggested that they may } \\
\text { confer tolerance to cold stress. }\end{array}$ & $\begin{array}{l}\text { (Bowman et al. } \\
\text { 1997) }\end{array}$ \\
\hline $\begin{array}{l}\text { Paenibacillus darwinianus, } \\
\text { Colwellia psychrerythraea, } \\
\text { Planococcushalocryophilus, Pse } \\
\text { udoalteromonas haloplanktis, } \\
\text { Psychromonasingrahamii, psyc } \\
\text { hrophilic } \\
\text { archaeon Methanococcoides } \\
\text { burtonii, and } \\
\text { bacterium Desulfotalea } \\
\text { psychrophile }\end{array}$ & $\begin{array}{l}\text { Need to be } \\
\text { tested. }\end{array}$ & $\begin{array}{l}\text { Their activity, effectiveness, and symbiotic } \\
\text { relationship need to be tested under low } \\
\text { temperatures. }\end{array}$ & $\begin{array}{l}\text { They might be effective in } \\
\text { improving cold acclimation. }\end{array}$ & $\begin{array}{l}\text { (Dsouza et al. } \\
\text { 2014) }\end{array}$ \\
\hline $\begin{array}{l}\text { Microbacterium sp. (e.g., } \\
\text { M.smegmatis, M. sp. SK0812), }\end{array}$ & $\begin{array}{l}\text { Need to be } \\
\text { tested. }\end{array}$ & $\begin{array}{l}\text { Its activity, effectiveness, and symbiotic } \\
\text { relationship need to be tested under low } \\
\text { temperatures. }\end{array}$ & $\begin{array}{l}\text { It might be effective in } \\
\text { improving cold acclimation. }\end{array}$ & $\begin{array}{l}\text { (Shires and Steyn } \\
\text { 2001; Kang et al. } \\
\text { 2009) }\end{array}$ \\
\hline $\begin{array}{l}\text { Arthrobacter, Flavimonas, } \\
\text { Flavobacterium, Massilia, } \\
\text { Pedobacter and Pseudomonas }\end{array}$ & Active at $5^{\circ} \mathrm{C}$ & Tomato & $\begin{array}{l}\text { Improved germination, growth, } \\
\text { and tolerance to chilling stress of } \\
15^{\circ} \mathrm{C} \text { by reducing membrane } \\
\text { damage and inducing antioxidant } \\
\text { activity }\end{array}$ & $\begin{array}{l}\text { (Subramanian et } \\
\text { al. 2016) }\end{array}$ \\
\hline
\end{tabular}




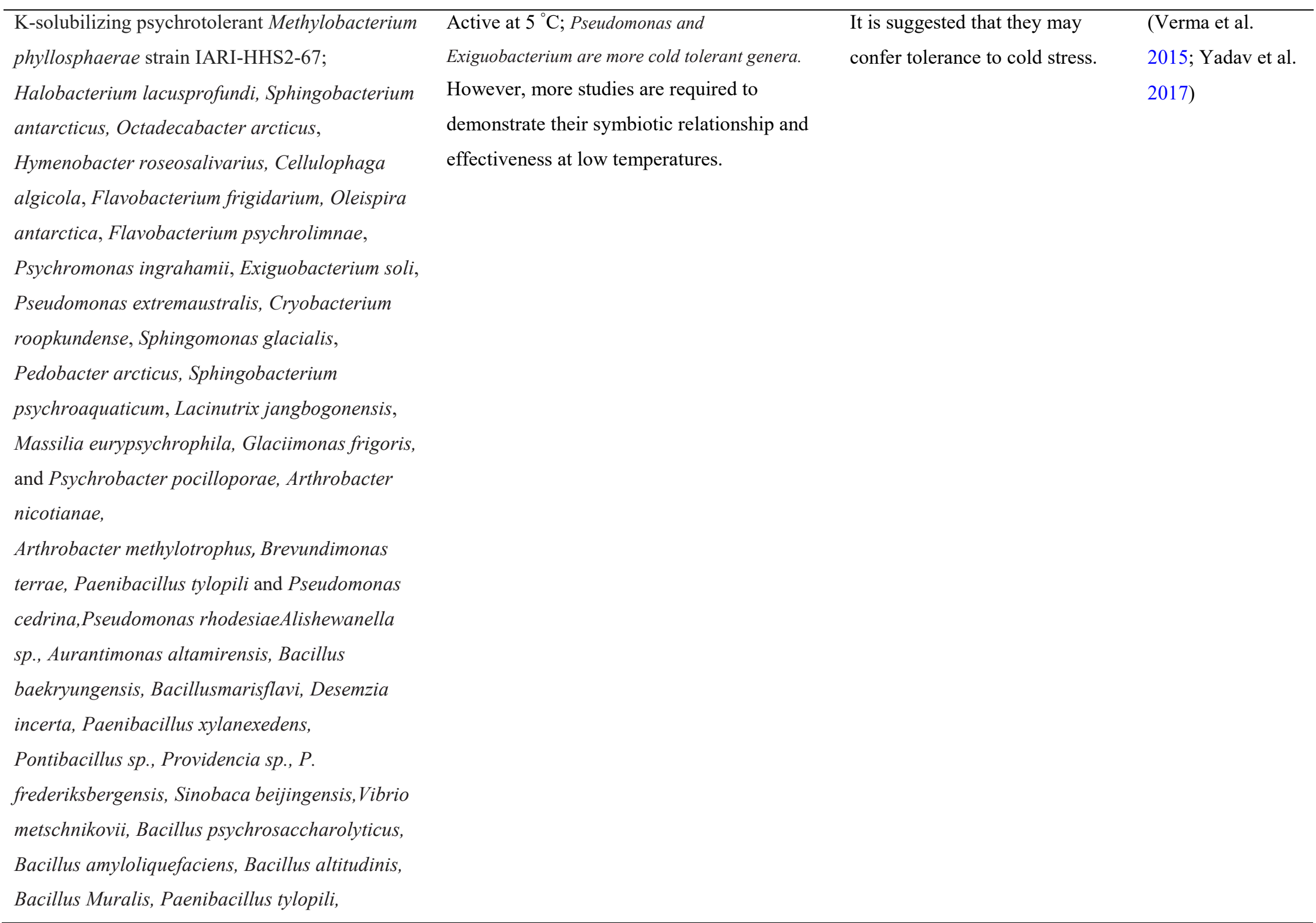




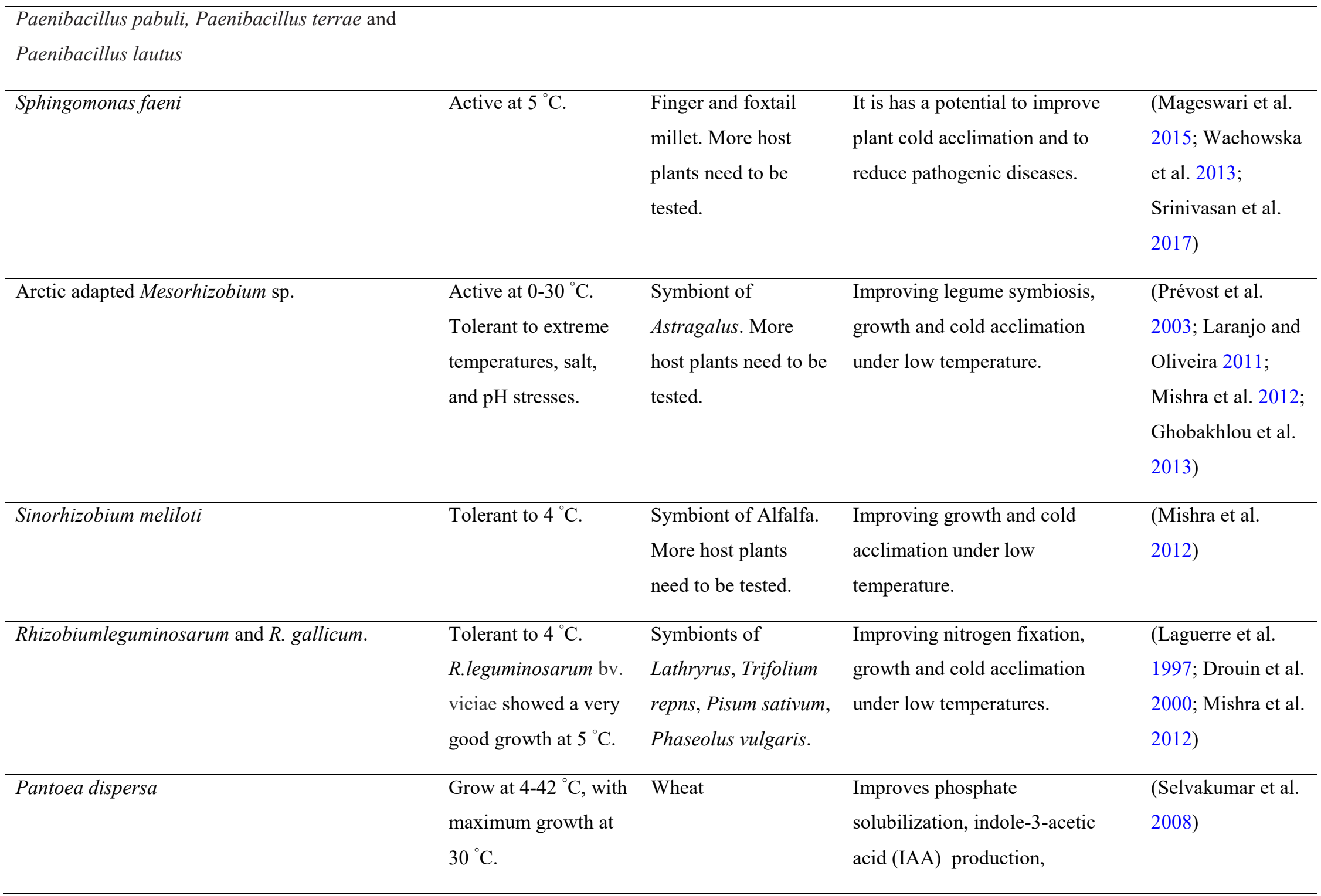




\begin{tabular}{|c|c|c|c|c|}
\hline & & & $\begin{array}{l}\text { siderophore and hydrocyanic acid } \\
\text { production and thus plant growth } \\
\text { and tolerance to biotic and } \\
\text { abiotic stresses. }\end{array}$ & \\
\hline Pseudochrobactrum kiredjianiae A4 & $\begin{array}{l}\text { P. kiredjianiae A4 is } \\
\text { a cold-adapted strain } \\
\text { from cave that } \\
\text { tolerate prolong low } \\
\text { light, temperature and } \\
\text { nutrient, but high } \\
\text { humidity and salinity } \\
\text { conditions. }\end{array}$ & Wheat & $\begin{array}{l}\text { Improving root and shoot growth, } \\
\text { fungal disease resistance, } \\
\text { antioxidant enzyme activity, } \\
\text { plant growth promotion } \\
\text { compounds like IAA, salicylic } \\
\text { acid (SA), and siderophore under } \\
\text { microgravity. }\end{array}$ & $\begin{array}{l}\text { (Fu et al. 2017; } \\
\text { Qin et al. 2017) }\end{array}$ \\
\hline Bacillus amyloliquefaciens & $\begin{array}{l}\text { B. amyloliquefaciens } \\
\text { is a cold adapted } \\
\text { strain; however, its } \\
\text { threshold activity } \\
\text { need to be tested. }\end{array}$ & Rice & $\begin{array}{l}\text { Improves crop performance and } \\
\text { tolerance to multiple abiotic } \\
\text { stresses. }\end{array}$ & $\begin{array}{l}\text { (Shahzad et al. } \\
\text { 2017; Tiwari et al. } \\
\text { 2017; Yadav et al. } \\
\text { 2017) }\end{array}$ \\
\hline
\end{tabular}


Table 3. Effects of plant-yeast symbiosis on plant tolerance to cold stress

\begin{tabular}{|c|c|c|c|c|}
\hline Yeast & Activity threshold & Host plant & Function & Reference \\
\hline Candida tropicalis & Need to be tested. & $\begin{array}{l}\text { Its activity, effectiveness, and } \\
\text { symbiotic relationship need to be } \\
\text { tested under low temperatures. }\end{array}$ & $\begin{array}{l}\text { It might be effective in } \\
\text { improving cold acclimation. }\end{array}$ & (Kang et al. 2009) \\
\hline $\begin{array}{l}\text { Cold-active basidiomycetous psychrophilic yeast } \\
\text { Mrakia frigida, Mrakia robertii sp. nov., Mrakia } \\
\text { blollopis sp. nov. and Mrakiella niccombsiisp. } \\
\text { nov. and Rhodotorula }\end{array}$ & $\begin{array}{l}\text { All genera can grow } \\
\text { at }-1{ }^{\circ} \mathrm{C}\end{array}$ & More studies are required. & $\begin{array}{l}\text { It is suggested that they may } \\
\text { confer tolerance to cold } \\
\text { stress. }\end{array}$ & $\begin{array}{l}\text { (Margesin et al. } \\
\text { 2005; Thomas-Hall } \\
\text { et al. 2010; Tsuji, } \\
\text { 2016) }\end{array}$ \\
\hline
\end{tabular}


Table 4. Effects of plant-bacteria-fungi symbiosis on plant tolerance to cold stress

\begin{tabular}{|c|c|c|c|c|}
\hline Bacteria-fungi & $\begin{array}{l}\text { Activity } \\
\text { threshold }\end{array}$ & Host plant & Function & Reference \\
\hline $\begin{array}{l}\text { Bacteria } \\
\text { Pseudomonas striata } \\
\text { Bradyrhizobium; } \\
\text { Azospirillum spp;; } \\
\text { Pseudomonas striata; } \\
\text { Fungi } \\
\text { Penicillium variable }\end{array}$ & $\begin{array}{l}\text { Need to be } \\
\text { tested. }\end{array}$ & $\begin{array}{l}\text { Their activity, effectiveness, and symbiotic } \\
\text { relationship need to be tested under low } \\
\text { temperatures in different host plants. }\end{array}$ & $\begin{array}{l}\text { They have been effective in improving } \\
\text { antioxidant activities, biosynthesis of } \\
\text { photosynthetic pigments, nutrient uptake, } \\
\text { and biomass production and thus might be } \\
\text { useful for cold acclimation. }\end{array}$ & $\begin{array}{l}\text { (Mishra 2011; Mishra et } \\
\text { al. 2012) }\end{array}$ \\
\hline $\begin{array}{l}\text { Pseudomonas spp. } \\
\text { NARs1 fungi }+ \\
\text { Rhizobium } \\
\text { leguminosarum-PR1 } \\
\text { (Tables 1, 2, and 4) }\end{array}$ & $\begin{array}{l}\text { Need to be } \\
\text { tested. }\end{array}$ & $\begin{array}{l}\text { Lentil (Lens culinaris L.). Their activity, } \\
\text { effectiveness, and symbiotic relationship } \\
\text { need to be tested under low temperatures in } \\
\text { different host plants. }\end{array}$ & $\begin{array}{l}\text { Effectively promoted iron acquisition, } \\
\text { nutrient uptake ( } \mathrm{P} \text { and } \mathrm{N}), \mathrm{CHL} \text { content, and } \\
\text { growth of co-inoculated lentil. It is } \\
\text { suggested that they may confer tolerance to } \\
\text { cold stress. }\end{array}$ & (Mishra 2011) \\
\hline
\end{tabular}

